\title{
Students' MATHEMATICAl COMMUniCATION ABILITY AND DisPosition IN THE IMPLEMENTATION OF MICRO DIDACTIC DESIGN AT JUNIOR HIGH SCHOOL
}

\author{
Hidayu Sulisti $^{1)}$, Sugiatno ${ }^{2)}$, Silvia Sayu ${ }^{3)}$ \\ 1) Universitas Tanjungpura, Pontianak, Indonesia \\ E-mail: hidayusulisti@gmail.com \\ ${ }^{2)}$ Universitas Tanjungpura, Pontianak, Indonesia \\ E-mail: giatno66@gmail.com \\ ${ }^{3)}$ Universitas Tanjungpura, Pontianak, Indonesia \\ E-mail: silviasayu88@gmail.com
}

\begin{abstract}
The reasons for conducting this research are that some teachers have taken inappropriate learning strategies and that students' mathematical disposition and mathematical communication ability in learning are still low. The Didactical Design Research (DDR) method begins with preliminary study on 28 eighth graders (junior high schoolers), aiming at exploring the students' learning obstacles to develop a micro didactic design. This micro didactic design is then implemented to the same students, after being subjected to validation process. The research results indicate that the learning using micro didactic design can minimize students' learning obstacles and this, eventually, positively contributes to students' mathematical communication ability and disposition in materi algebraic factorization. From the data analysis results, it is found that the price of effect size for micro didactic design learning on mathematical communication ability is 1.07 , and from Table $\mathrm{Z}$ it is found that its contribution is $35.77 \%$. Meanwhile, the price of effect size for micro didactic design learning on mathematical disposition is 0.2 , and from Table $\mathrm{Z}$ it is found that its contribution is $7.93 \%$.
\end{abstract}

Keywords: Learning obstacle; Mathematical communication ability; Mathematical disposition; Micro didactic

\section{INTRODUCTION}

The experts in National Research Council (NRC) (2001) suggest that the mathematical knowledge needed for one to succeed in the constantly changing world is the one related to what are taught at schools. Therefore, the mathematics taught at schools consists of selected parts, in order to develop students' abilities oriented towards science, knowledge and technology development. One of parts of mathematics is algebra.

Lacampagne et al. (1993) suggests that algebra is a study on patterns/relationship and function using various representations, including verbal, tabular, graphic, and symbolic representations. Algebraic ideas support mathematical works in many fields. Distribution and communication networks, laws of physics, population models, and statistical outcomes (NCTM, 2000; Walle et al.,
2010; Williams, 2011; Lacampagne et al., 1993) suggest similar opinions on algebra, i.e. that algebra support the mathematical works in many fields, for example as illustrated in the symbolic language of algebra. Therefore, algebra becomes a helpful tool to generalize arithmethic and represent pattern in daily life.

Some topics included in algebra at schools are: Using Symbols, Solving Equations, the Balancing Model, Writing Expressions, and Multiplying Algebraic Expressions (May, 2005; Walle et al., 2010). One of the sub-topics in Writing Expressions is algebraic factorization form. Algebraic factorization constitutes a fundamental skill students ought to have, in order to simplify complicated algebraic problems.

The objectives of teaching mathematics at schools are: (1) to communicate ideas using symbols, tables, diagrams, or other media to make things or problems clearer; (2) to have the attitude of respecting the use of mathematics in life, i.e. 
being courious, attentive, and interested in learning mathematics, as well as persistent and confident in solving problems (BSNP, 2006). These learning objectives have something to do with mathematical communication (NCTM, 2000), and mathematical disposition (NRC, 2001).

Mathematical communication plays an important role in mathematics learning since it is through this mathematical communication that students can organize and consolidate their mathematical thinking. This statement is in line with the definition of mathematics learning by some experts in NCTM (2000). They argue that a communication process helps students build meanings and revise their comprehension. They argue that communication process helps students build meanings and revise their comprehension. When students are challenged to think and to reason about mathematics and to communicate the results of their thinking to others orally or in writting, they learn to explain and to convince. Listening to other's explanation gives students a chance to develop their own comprehension.

Student's mathematical communication ability will be less optimal if it is not supported by the positive attitudes accompanying it. This is important considering that positive attitudes towards mathematics will be positively correlated with mathematics learning achievement. These attitudes are called as mathematical disposition (Walle et al., 2010). According to Saragih (2017) approaching their high school period, students have positive attitude towards mathematics, yet this is slowly decreasing. Students with positive attitude towards mathematics have such characteristics as looking serious in learning mathematics, completing their tasks well and punctually, actively participating in discussion, completing their homeworks thoroughly, and finishing it in timely manner. Mathematical disposition is a character or personality an individual needs to succeed in learning mathematics. Students need mathematical disposition to stay motivated in the face of problems, take the responsibility in their learning and develop good working behavior in mathematics.

Mathematical disposition also influences students' mathematical communication ability. In NCTM (1989), mathematical disposition includes the ability to take risks and explore varied problem solutions, persistence to solve challenging problems, taking responsibility to reflect on their work, appreciate the power of communication of mathematics language, willingness to ask and propose other mathematical ideas, willingness to try to explore mathematical concepts differently, having confidence to their abilities, and see problems as challenges.

However, in reality, some mathematics learnings have not fulfilled these two learning objectives. Based on personal experience as a mathematics teacher for more than two years at Junior High School (SMP) of Assalam Islamic Boarding School, Pontianak, it is found that most students think mathematics a fairly difficult subject and one of the most difficult topics in mathematics is algebra for its abstract nature. Students learn passively, with not much knowledge on what, how and for what purpose is this sub-topic is given. Students tend to imitate or memorize procedure without knowing the meaning of algebraic symbols. This happens because students' mathematical disposition is usually low. They think mathematics is frightening, leading them to being less confident in mathematics. Furthermore, this makes students' mathematical communication ability fail to develop optimally.

It is strongly suspected that this results from the learning strategy applied by mathematics teacher in the classroom which does not involve students too much. This leads to students acting merely more like recipients of the material, resulting in the students' high dependence on the teacher. This is as suggested by O'Dell (2017) who finds that many students think they do not have the "mathematics gene" and are frigthened of or anxious about mathematics. Lampert (1990) has evaluated the phenomenon, by conducting studies, in which fifth graders are involved in many common mathematical practices. He finds that when students are involved in the practice, they act as mathematics experts and behave differently from those who do not have this experience. Brendefur and Frykholm (2000) suggests that in mathematics learning, teachers tend to dominate discussions using expository approach, asking closed questions, and students are not given the opportunity to communicate their strategies, ideas, and thoughts, resulting in the learning passively accepted by students.

Carpenter et al. (2005) state that in the American curriculum, there is a serious discontinuity between the arithmetic that students learn in elementary school and the algebra they hope to learn in the higher grades. This is supported by Cortes, Nomi, and Goodman (2013) who suggest that in America, students in urban high schools are very diconcerting. These schools struggle with two related problems. Firstly, many students do not obtain the passing scores in early learning which are considered as a prerequisite for more advanced subjects. Secondly, students are at high risk of failing to obtain their high school diploma. One theory for this low level of senior high school graduation is their failure in early learning such as algebra, in such a way that it interferes with subsequent learnings, and puts students on track which makes their graduation pretty difficult.

In the NCTM document (1989), it is stated that "using mathematics to explore real world phenomena is one means of developing mathematical disposition. This means that, the process can indirectly develop mathematical communication ability. Therefore, to improve mathematical communication ability and disposition, Realistic Mathematics Education (RME) learning model is chosen to be the first model developed in the Netherlands by Freudenthal (2002). RME combines views on what mathematics is, how students learn mathematics and how mathematics must be taught. RME is a mathematics learning that involves real-world context so that it can be a meaningful learning experience for students (Wubbels, 1997; Panhuizen, 2000; Freudenthal, 2002; Panhuizen, 2003).

$\mathrm{RME}$ researchers continue to contribute to the progress of student education, especially their understanding in mathematics. In Sparingga, Mukhni, and Yerizon's (2018) 
research, it is stated that the mathematical communication ability of those students who learn using RME approach are better than that of students who learn using conventional learning method. Syamsudin, Afrilianto, and Rohaeti's (2018) research concludes that mathematical communication ability can be improved using RME approach. This conclusion is drawn from the fact that the more actively students are interacting with their fellow students or teachers, the better they are in transforming information in story questions or problems into a mathematical model or into mathematical expression. Laurens et al. (2018) in their research also suggest that RME approach becomes one of the most effective approaches in nurturing motivation, selfconfidence, problem-solving skills, and reasoning which in turn improve cognitive achievement. Meanwhile, Safitri et al. (2017) concludes that students' mathematical disposition are better after using RME.

Panhuizen (2003) explains specifically students' comprehension advancement in a mathematics sub-topic, i.e. integer operation. He distinguishes the progress of RME in two levels of work in mathematical development, namely micro didactic and macro didactic for student growth. The micro didactic clarifies how comprehension increases in the context of one or two lessons, while macro didactic is related to the comprehension advancement in a longer term. Both of these perspectives play a key role in stimulating students' growth, yet the discussions on them in Indonesia can be said as relatively lacking.

Considering the explanation above, it is important for teachers to develop students' positive disposition towards mathematics and their mathematical communication, using a meaning learning approach to students. Therefore, the researchers in interested to conduct research on students' mathematical communication ability and disposition in the implementation of micro didactic design at junior high school.

\section{RESEARCH METHOD}

The research design used here is didactic one with qualitative and quantitative approaches. In this research, the learning obstacles students encounter in algebraic factorization topic are explained as viewed from their mathematical communication ability and the ways to deal with these obstacles using micro didactic design are described.

The procedure for developing the micro didactic design refers to the stages of Didactical Design Research (DDR) developed by Suryadi (2010). The stages include: (1) Didactic Situation Analysis Before Learning; Metapedadidactic Analysis; (3) Retrospective Analysis.

In the didactic situation analysis before learning stage, the steps taken include: (1) determining the mathematics topic to be the subject of research, namely the algebraic factorization of distributive law; (2) studying algebraic factorization of distributive law; (3) preparing the research instruments in the form of initial student ability tests (tes kemampuan siswa or TKS) according to mathematical communication ability indicators, and initial questionnaires according to mathematical disposition indicators; (4) holding the initial TKS and distributing the initial questionnaire, then proceeding with the interview to those respondents identified as experiencing learning obstacles in the algebraic factorization of distributive law topic; (5) analyzing the results of instrument test in the form of TKR questions, questionnaires and interview to identify students' learning obstacle on the algebraic factorization of distributive law topic; (6) preparing a micro didactic learning design which matches the students' identified learning obstacles.

In the metapedadactic analysis stage, the steps taken are: (1) implementing the prepared micro didactic design; (2) analyzing the situation and students' response when the micro didactic design is implemented. In the retrospective analysis stage, the steps taken include: (1) analyzing the implementation of the learning process with micro didactic design based on the observation sheets as observed by three observers; (2) holding final TKS, final questionnaires, and interviews with seven students, namely AR, AS, AWY, EM, MA, RM, and RQ to discover their learning obstacles, and what influences they have on their mathematical communication ability and disposition; (3) preparing research report.

This research aims at explaining the process of micro didactic implementation, in which the micro didactic itself is used to improve and anticipate things that inhibit students in learning, thus the subjects in this research are those students who have studied algebraic factorization topic and experience problems in learning, namely eighth graders junior high school.

\section{RESULT AND DISCUSSION}

A. Result

Based on the research objectives on mathematical communication ability and disposition in the implementation of micro didactic design of junior high schoolers in algebraic factorization topic, the following results are obtained.

\section{1) Identification of Learning Obstacles Before and After Micro Didactic Design Implementation}

Students' learning obstacles are identified by analyzing the results of initial mathematical communication ability test held on 23 July 2018. In addition to questions, the analysis is also performed using interview to several students. The interview questions are based on the analysis of previous students' written answers.

In general, the learning obstacles that students encounter based on the initial TKS results include: (1) students have not known similar terms; (2) students cannot distinguish algebraic expressions from algebraic equation yet; (3) students cannot distinguish factors from GCD yet; (4) students have not known fractions calculation operation; (5) students have single representation forms. As a result, what students have regarding representation from mathematical narrative in the questions do not match what they express. In other words, students are hindered in the translation process of representation; (6) students are hindered in the 
transformation process of representation, where students make mistakes in calculating arithmetic/algebraic problems.

\section{2) Teaching and Learning Process using Micro Didactic Design}

The teaching and learning using micro didactic design are applied on 26 July based on the micro didactic design steps. This can be seen from what the three observers see when the researchers are teaching. From their observation, the three observes think that the teaching and learning using micro didactic design performed by the researchers are good. The accomplishment percentage of teachers' activities is $87 \%$ and classified as excellent. Meanwhile, on the student part, the average accomplishment percentage is $77 \%$ and classified as good.

\section{3) Test Results after Micro Didactic Design Implementation}

The results of initial and final questionnaires per indicator can be seen in Table I and Table II.

TABLE I

RESULTS OF INITIAL AND FINAL QUESTIONNAIRES

\begin{tabular}{ccc}
\hline \multirow{2}{*}{ Indicator } & \multicolumn{2}{c}{ Questionnaire } \\
\cline { 2 - 3 } & Initial & Final \\
\hline Self-confidence & 76 & 82 \\
Curiousity & 77 & 77 \\
Persistence & 83 & 80 \\
Flexibility & 70 & 71 \\
Average & $\mathbf{7 5}$ & $\mathbf{7 6}$ \\
\hline
\end{tabular}

TABLE III

RESULTS OF INITIAL DAN FINAL TKS

\begin{tabular}{lcc}
\hline \multirow{2}{*}{ Indicator } & \multicolumn{2}{c}{ TKS } \\
\cline { 2 - 3 } & Initial & Final \\
\hline Expressing mathematical ideas in writing. & 0 & 21 \\
Understanding mathematical ideas in writing. & 14 & 32 \\
Expressing daily events in mathematical & 4 & 17 \\
language or symbols. & 0 & 23 \\
Compiling arguments. & $\mathbf{5}$ & $\mathbf{2 2}$ \\
Average & & \\
\hline
\end{tabular}

\section{B. Discussion}

In this part, the discussion is focused on learning obstacles the students encounter and the process of implementing micro-didactic design. Additionally, the influence and contribution of the implementation of micro didactic to students' mathematical communication skills and mathematical disposition are also discussed.

To describe the learning obstacles that students encounter, the first step is to give an initial TKS, an initial questionnaire and an interview to them in order to reveal the research subjects' initial ability. From the results of initial TKS, initial questionnaire and interview, the learning obstacles experienced by students in solving problems regarding algebraic factorization are found.

And the learning obstacles encountered by students are: (1) students have not known similar terms; (2) students cannot distinguish algebraic expressions from algebraic equation yet;
(3) students cannot distinguish factors from GCD yet; (4) students have not known fractions calculation operation; (5) students have single representation forms. As a result, what students have regarding representation from mathematical narrative in the questions do not match what they express. In other words, students are hindered in the translation process of representation; (6) students are hindered in the transformation process of representation, where students make mistakes in calculating arithmetic/algebraic problems.

After obtaining students' learning obstacles in algebraic factorization topic, the next step is preparing a micro didactic design which will help students deal with these learning obstacles. The teaching and learning using micro didactic design are prepared with a time allotment of $3 \times 40$ minutes. When the micro didactic design is implemented, the researchers perform a metapedadidactic analysis. This metapedadidactic analysis is the effort of analyzing the situation and students' responses during the teaching and learning.

The teaching and learning process begins with teachers asking questions on algebraic factorization which students have previously learned. Students have been prepared with a apperception in order to remind them of algebraic factorization topic. In this process, students' self-confidence and curiousity level begin to develop. This is characterized by students' high enthusiasm to participate in a discussion on previous learning topic related to algebraic factorization. This is supported by Walle et al. (2010) who suggests that learning to communicate in mathematics can encourage interaction and exploration of mathematical ideas in classroom when students learn in an active verbal environment.

After being provided with apperception, students are grouped into seven groups. Each group consists of four. Students are asked to work together in groups in solving the problems given by the researchers. This encourages students to develop their mathematical communication. This is supported NCTM (1989) document wherein it is stated that mathematical communication can take place when students work in cooperative groups, when a student explains algorithm to solve an equation, when a student presents a unique method to solve problems, when students construct and explain a graphic representation of a real-world phenomenon, or when students offer a notion on geometric figure. Before students perform the group discussion in teaching and learning, the researchers first explain the learning steps.

During the teaching and learning process, students are given a chance to solve the problem given using their natural strategy related to algebraic factorization context. This is in line with the level principle in Realistic Mathematics Education (RME), i.e. students should be able to solve provlems at their own level (Frudenthal, 2002). At this stage, students' self-confidence and persistence in working on mathematical tasks start to grow. Teachers walk around while paying attention to students' process in working on the tasks and give a scaffolding to the group who are confused in understanding the given tasks. 
The problems given to students are those problems whose flexibility gradually increases. This means the given problems are similar ones, yet they require students to find increasingly advanced strategies, thus students can express an algebraic factorization form by finding the common divisors. This is consistent with the "progressive schematization aspect in micro didactic design by Frudenthal (2002) who suggests that the progressive schematization method implies that mathematical concept process does not lie in the final stage of learning process, rather it lies in its initial process. Students can solve problems from introduction in relation to the context where the problem is presented. In other words, student can be flexible in solving algebraic factorization tasks.

In this progressive schematization stage, students' learning obstacles have been found which, therefore, cause students to have not been able to solve the given problems. The obstacle is that students cannot memorize multiplication well. This is a problem since to be able to factorize, students need to understand multiplication first. This also prevent them from finding their natural strategies in expressing an algebraic factorization form. In this case, the researchers give a scaffolding in the form of multiplication using the socalled jarimatika method.

After passing the progressive schematization stage, next is to involve a problem context which offers students a chance to develop a formal mathematical language. This stage aims at allowing students to change daily events into mathematical sentences, particularly algebraic factorization.

After passing this stage, students enter a model which is connexted as a strength to move forward. In RME, a model is viewed as a representation of problem situation, which should reflect the important aspects of the mathematical concept and structure relevent to the problem situation, yet it can have different manifestation (Panhuizen, 2003). This begins with the real situation that students have known, i.e. piggybank model which they have finished previously. Later, the "model of" of this situation is found and then followed by the finding of "model for" of this form, until the problem solution is obtained in the form of standard mathematical knowledge.

The development of mathematical language is born from the need to trace the most effective way in counting all moneys in the piggybank from the piggybank whose amount of money is known. Initially, this language is related to its context. Gradually, the piggybank context loses its narrative feature and takes more model characters.

Later, the significance of interaction principle in RME implies that education should give students a chance to share their strategies and findings one another. Listening to what others find and discuss can help students find ideas to revise their strategies (Frudenthal, 2002). This can be seen from students worksheet which indicates answers using more advanced strategies, as a result of the finding they previously experience.

According to Suryadi (2010) when teachers create a didactic situation, there are three possibilities to occur in relation to students' response to the situation in the teaching and learning, i.e. the teaching and learning take place entirely as predicted by teachers, some are as predicted, or nothing is as predicted. In this stage, one group answers beyond the prediction. Students in this group incorrectly solves the given problems.

At each teaching and learning phase, every group gets their turn to present the results of their group discussion, and every student has the right to ask or give comments under the facilitators, i.e. the researchers, guidance. In the beginning of teaching and learning, students seem a little bit in doubt to present the results of their group discussion in front of the class. However, in the middle of the teaching of learning, students begins to have self-confidence and enthusiasm to present the results of their group discussion.

After the group discussion ends, each group is given a chance to draw conclusions from their discussion during the teaching and learning. These conclusions can be used as a reflection on the entire teaching and learning on algebraic factorization they have done.

Overall, it can be concluded that most students are still confined with the learning method they previously receive. Some students only merely copy what the teachers use as an example. As a result, these students are less capable of solving the problems using their own strategies. This is confirmed by their teacher who states that the teaching and learning using expository approach performed by the teacher has cause students have low self-confidence on their own ability. In solving mathematical problems, students prefer following the steps their teachers show them or taken by most of their friends, rather than their own way. In line with this, Brendefur (2000) suggests that in mathematics learning, teachers tend to dominate the discussion using expository approach, asking closed questions, and students are not given enough opportunity to communicate their strategies, ideas, and thoughts, resulting in the learning passively accepted by students. Therefore, in the results of mathematical communication ability test, some students are found cheating and complete the disposition questionnaire dishonestly. This is quite unfortunate considering that during the interview with the relevant students, it is evident that these students have the ability to solve the mathematical problems by themselves. Students' dishonesty in completing the mathematical communication ability test questions and mathematical disposition questionnaire result in the inaccurate description of these students' condition and eventually affects the research results.

After the teaching and learning ends, an analysis is done to evaluate the teaching and learning using the micro didactic design which have been performed. Upon this analysis, a final TKS is conducted on 30 July. It is then followed with interview with students one at a time on 2 August. From this final TKS and interview, it is found that some students still experience some learning obstacles including: (1) students have not known similar terms; (2) students cannot distinguish factors from GCD yet; (3) students have not known representation transformation, in which students make a mistake in counting GCD; (4) students have not known transition from verbal to symbolic 
representation forms; (5) students have not known translation from visual to symbolic representation forms; and (6) students have not known the types of two-dimensional figure.

Furthermore, the results of initial and final TKS statistical test of students' mathematical communication ability indicate that the students' average mathematical communication ability before the micro didactic design is implemented is not the same with students' average mathematical communication ability after the micro didactic design is implemented. This can be seen from $t_{0}$ value $>t_{(0,05}$; 27) i.e. $(5.700>1.703)$. This means the implementation of micro didactic design has an influence on students' mathematical communication ability. This can be seen from the students' average score of initial TKS at 5, and that of final TKS at 22. Students' TKS score in mathematical communication ability increases by 17 . This influence gives significant contribution to students' mathematical communication. This is supported by the calculation using effect size formula of 1.07 for great criteria, or developing by $35.77 \%$. This development is consistent with the extent of development occuring between students' initial and final TKS results. Based on the results of statistical calculation explained earlier, it can be concluded that the use of micro didactic design gives significant influence on students' mathematical communication ability. This is based on the observation which indicates that having finished the micro didactic teaching and learning, students can play an active role in group discussions and creatively find solutions to the problems they encounter, interact one another with friends and teachers and exchange ideas so that their insights and thoughts develop. In other words, students mathematical communication ability has developed. This is as suggested in NCTM (1989), i.e. that mathematical communication can take place when students work in a cooperative group.

Fauzan (2002) suggests that realistic mathematics learning not only can improve students' reasoning ability and creativity, rather it can also improve their mathematical communication ability. This is supported by the results of study conducted by Nopiyani, Turmudi, and Prabawanto (2016) who find that realistic mathematics learning can improve junior high schoolers' mathematical communication ability.

The results of initial and final questionnaire on students' mathematical disposition are processed and it is found that students' average score before and after the micro didactic design is implemented is different. This can be seen from the sig value of 0.434 (> 0.05). This means micro didactic design has no influence on students' mathematical disposition. However, when using Wilcoxon test of two paired samples via SPSS version 18, it is found that students' average mathematical disposition prior to macro didactic design implementation, there is an increase by 1 score of questionnaire or around $7.93 \%$ which is contributed by micro didactic. This can be shown from the calculation using Effect Size formula of 0.2 for small criteria, or developing by $7.93 \%$, and the result for initial questionnaire is 75 and for final questionnaire it is 76.
This is to the contrary of Safitri et al. (2017) who find that there is a significant effect of RME implementation on the nine graders' mathematical disposition at State Senior High School 4 Padang-sidimpuan, i.e. as seen from the comparison of average scores from pre-test and post-test. The average prior to RME is 70.00 and after RME is 78.95 . This phenomeno arises since students have had good disposition before they receive micro didactic design teaching and learning in algebraic factorization topic, hence the improvement that students have after the teaching and learning using micro didactic design is not too significant.

Lumentut, Ali, and Hasbi's (2015) research discuss algebra block-aided NHT-type cooperating learning model in improving eighth graders' learning outcome for algebraic term factorization topic. He finds in the cycle 1 final test that 14 students have accomplished and 10 have not accomplished the learning. Meanwhile, in cycle II which is conducted in one meeting, 22 students are found to have accomplished and only 2 students have not accomplished the learning. This means, for cycle I which is performed in two meetings, an increase of $58.33 \%$ accomplished students is obtained.

Ardiansari (2017) in her research on the application of recitation-supported Group Investigation learning model concludes that this learning model can improve eighth graders learning outcome. This is proven from the increased percentage of students' classical learning accomplishment in cycle I to cycle 2 which are conducted for four times by $48 \%$.

This is also in line with Rahim's (2010) research on Think Pair Share approach, who concludes that students' mathematics learning achievement in algebraic term factorization topic can be improved using Think Pair Share approach. The obtained results are that for the initial test of cycle I which is held in three meetings students experience an increase by $17.5 \%$. From cycle I to cycle II which is held in three meetings, students improve by $17.5 \%$ and from cycle II to cycle III which is held in two meetings students improves by $15 \%$. This shows that the efforts to improve students' learning achievement need the right timing.

Therefore, micro didactic design teaching and learning which is initially planned to be done only in one meeting, needs to be done in several meetings to allow an optimal development of students' mathematical communication ability and disposition in learning algebraic factorization topic.

\section{CONCLUSION AND SUGGESTION}

\section{A. Conclusion}

Based on the problem formulation proposed regarding students' mathematical communication ability and disposition in the implementation of micro didactic design at junior high school in algebraic factorization topic, it can be concluded that: (1) the learning obstacles that students experience in algebraic factorization topic are that students have not known similar terms, cannot distinguish algebraic expression from algebraic equation yet, cannot distinguish factor from GCD, have not known fractions calculation 
operation; have not known translation from verbal to symbolic representation forms, have not known translation from visual to symbolic representation forms, find it difficult to transform representation, in which students make mistake in calculating arithmetic/algebraic problems; (2) the micro didactic design is performed in stages, namely the analysis prior to teaching and learning, metapedadidactic and retrospective stages. The micro didactic design is developed in the form learning scenario and students worksheet. Based on the observations from observers during the teaching and learning process done by the researchers, it is found that the average accomplishment score in the activities performed by teachers is 87, and the average score of accomplishment in students' activities is 77 . This means the teaching and learning using micro didactic design are accomplished well; (3) from the results of data analysis, it is found that micro didactic design has some influence on students' mathematical communication ability; (4) also from the data analysis, it is found that the micro didactic design has no effect on students' mathematical disposition. However, an increase of 1 score of questionnaire occurs. This is shown by the initial questionnaire score of 75 and the final questionnaire score of 76; (5) based on the research results, it is found that the teaching and learning using micro didactic design has fair influence on students' mathematical communication. This influence has given positive contribution at $35.77 \%$. This development is in line with the extent of development occuring between students' initial and final TKS results. Despite the extremely low score of TKS results, students show a fairly good progress; (6) based on the research results, it is found that the teaching and learning using micro didactic design has fair influence on students' mathematical disposition. This influence gives a positive contribution at $7.93 \%$. This development is consistent with the result of initial questionnaire whose average score is 75 and classified as sufficient and the students' final questionnaire results whose average value is 76 and classified as good.

\section{B. Suggestion}

Based on the research results and discussion, the researchers would like to offer some suggestions: (1) teachers need to improve their ability in designing, implementing and reflecting on the teaching and learning activities, by considering the condition of students and what they know; (2) the learning obstacles encountered students need to be dealt with by teachers, because the results will forever be false conception in student when left untouched.

\section{REFERENCES}

Ardiansari, L. (2017). Penerapan Model Pembelajaran Kooperatif Tipe Group Investigation didukung Metode Resitasi untuk Meningkatkan Hasil Belajar Siswa Kelas VIII SMPN 1 Bangorejo pada Materi Faktorisasi. Aljabar. Ar-Risalah, 15, 38-51.

Brendefur, J., and Frykholm, J. (2000).“ Promoting Mathematical Communication in The Classroom: Two
Preservice Teachers' Conceptions and Practices, Journal of Mathematics Teacher Education, 3, 125-153.

BSNP. (2006). Standar Isi untuk Satuan Pendidikan Dasar dan Menengah. Jakarta: BSNP.

Carpenter, T. et al. (2005). Algebra in Elementary School: Developing Relational Thinking, International Journal on Mathematics Education, 37, 53-59.

Cortes, Nomi, and Goodman. (2013). A Double Dose of Algebra. Cambridge: Harvard Kennedy School, 13, 1-7.

Fauzan, A. (2002). Applying Realistic Mathematics Education (RME) in Teaching Geometry in Indonesian Primary School. Tesis. University of Twente, Enschede.

Frudenthal, H. (2002). Revisiting Mathematics Education. London: Kluwer Academic Publishers.

Lacampagne, C.B., Ed, etc. (1993). The Algebra Initiative Colloquium, Educational Research and Improvement, 2.

Lampert, M. (1990). When The Problem is not The Question and The Solution is not The Answer: Mathematical knowing and teaching, American Educational Research Journal, 27, 29-63.

Laurens et al. (2018). How Does Realistic Mathematics Education (RME) Improve Students' Mathematics Cognitive Achievement?, EURASIA Journal of Mathematics. Science and Technology Education, 14, 569-578.

Lumentut, C.P., Ali, M.T.M., and Hasbi, M. (2015). Peningkatan Hasil Belajar Siswa Kelas VIII SMPN 14 Palu dengan Model Pembelajaran Kooperatif Tipe NHT berbantuan Blok Aljabar pada Materi Perkalian Faktor Bentuk Aljabar. Jurnal Elektronik Pendidikan Matematika Tadulako, 2, 238-248.

May, T.C. (2005). Teaching Maths to Pupils with Different Learning, Styles. London: Paul Chapman Publishing.

National Council of Teachers of Mathematics (NCTM). (1989). Curriculum and Evaluation Standards for School Mathematics. Reston, VA: author.

National Council Of Teachers Of Mathematics (NCTM). 2000. Principles and Standards for School Mathematics, Reston: NCTM.

National Reseach Council (NRC). (2001). Adding It Up: Helping Children Learn Mathematics, Washington, DC: National Academy Press.

Nopiyani, Turmudi, and Prabawanto. (2016).“ Penerapan Pembelajaran Matematika Realistik Berbantuan GeoGebra untuk Meningkatkan Kemampuan Komunikasi Matematis Siswa SMP. Jurnal Pendidikan Matematika STKIP Garut, 5, 45-52.

O' Dell, Jenna R. (2017). Beyond Problem-Solving: Elementary Students Math-ematical Dispositions when Faced with The Challenge of Unsolved Problems. thesis and dissertations. Illinois State University, AS.

Panhuizen, Van den Heuvel M. (2000). Mathematics Education in The Netherlands: A Guided Tour. Freudenthal Institute Cd-rom for ICME9. Utrecht: Utrecht University.

Panhuizen, Van den Heuvel M. (2003). The Didactical Use of Models in Realistic Mathematics Education: An 
Example from A Longitudinal Trajectory on Percentage. Educational Studies in Mathematics, 54, 935.

Rahim, U. (2010). Meningkatkan Prestasi Belajar Matematika Siswa pada Pokok Bahasan Faktorisasi Suku Aljabar melalui Pendekatan Struktural Think Pair Share (TPS) Siswa Kelas VIII 2 SMPN 4 Kendari. MIPA, 9, 78-86.

Safitri, et al. (2017) "Impact of Indonesian Realistic Mathematics Approach to Students Mathematic Disposition on Chapter Two Composition Function and Invers Fungtion in Grade XI IA-1 SMA Negeri 4 Padangsidimpuan," International Journal of Novel Research in Education and Learning, 4, 93-100.

Saragih, S. (2017). Menumbuhkembangkan Berpikir Logis dan Sikap Positif terhadap Matematika melalui Pendekatan Matematika Realistik. ResearchGate.

Sparingga, Mukhni, and Yerizon. (2018).“ Kemampuan Komunikasi Matematis Siswa dengan Pendekatan
Realistic Mathematic Education. Jurnal Pendidikan Matematika, 7, 7-12.

Suryadi, D. (2010). Menciptakan Proses Belajar Aktif: Kajian dari Sudut Pandang Teori Belajar dan Teori Didaktik." Proc. Pendidikan Matematika, 1.

Syamsudin, Afrilianto, and Rohaeti. (2018). Meningkatkan Kemampuan Komunikasi Matematik Siswa Kelas VIII SMP Negeri 2 Cariu pada Materi Sistem Persamaan Linier Dua Variabel dengan Pendekatan Realistic Mathematic Education (RME). Jurnal Pembelajaran Matematika Inovatif, 1, 313-324.

Walle, et al. (2010). Elementary and Middle School Mathematics., Ed.7. US: Pearson Education,.

Williams, T.G. (2011). Reaching Algebra Readiness (RAR). Preparing Middle School Students to Succeed in Algebra-The Gateway to Career Success., Rotterdam: Sense Publishers.

Wubbels, T. et al. (1997). Preparing Teachers for Realistic Mathematics Education. Educational Studies in Mathematics, 32, 1-28. 